\title{
A community study of severe mental retardation in the West Midlands and the importance of the fragile $\mathrm{X}$ chromosome in its aetiology
}

\author{
S BUNDEY, T P WEBB, A THAKE, AND J TODD \\ From the Department of Clinical Genetics, Infant Development Unit, Birmingham Maternity Hospital, \\ Edgbaston, Birmingham B15 $2 T G$.
}

SUMmaRY This paper describes a community based study of 156 boys with idiopathic, severe mental retardation. The boys were examined and a pedigree taken before the cytogenetic results were known. The prevalence of the fragile $\mathrm{X}$ chromosome among this group of boys was high: $9 \%$ in the whole group and $11 \%$ after 39 boys with specific features had been excluded. The fragile $\mathrm{X}$ syndrome is therefore an important cause of idiopathic, severe retardation. Its clinical features of large head, large testes, and IQ in the 35 to 70 range were often but not always present in the 14 boys identified in this study.

In the whole group, the recurrence of severe mental subnormality was high: 1 in 8 for brothers and 1 in 25 for sisters. This high recurrence was partly due to the fragile $\mathrm{X}$ syndrome, partly to $\mathrm{X}$ linked mental retardation not accompanied by cytogenetic abnormalities, and partly due to autosomal recessive disease. Autosomal recessive disease was perhaps higher in the West Midlands than elsewhere (such as British Columbia, for example ${ }^{1}$ ) because of the disproportionate contribution by Asian immigrants.

There have already been numerous surveys on the families of patients with idiopathic, severe mental retardation, but this further one was planned because of the recent realisation that the fragile $\mathrm{X}$ syndrome is a significant cause of mental retardation. It is a condition where prevention is possible, through identification of female carriers and the offer of antenatal diagnosis and therapeutic termination of affected pregnancies. Therefore we felt it important to estimate its frequency among retarded children so that it could be decided to what extent the new techniques required for the recognition of the fragile $X$ should be routinely available, or whether the test should be restricted to children who had certain clinical features.

\section{The fragile $\mathrm{X}$ syndrome}

Since the work of Davison ${ }^{2}$ and Turner and Turner ${ }^{3}$ it has become clear that $\mathrm{X}$ linked genes cause a significant proportion of severe mental retardation

Received for publication 8 September 1984

Accepted for publication 17 September 1984 in males. Lubs, ${ }^{4}$ Harvey et al, ${ }^{5}$ and Sutherland ${ }^{6}$ observed that one of the types of $\mathrm{X}$ linked mental retardation is associated with a structural abnormality at $\mathrm{Xq} 27-28$. This abnormality, or fragile site, is only revealed in folic acid and thymidine deficient media. The gene causing the mental retardation has been shown to be placed very close to the fragile site, namely at Xq27-28. The evidence comes from linkage studies in which this type of mental retardation has been linked in families to the loci for factor IX and G6PD deficiency. ${ }^{7}$

The pedigrees of boys with the fragile $\mathrm{X}$ syndrome do not always conform to the accepted criteria for $\mathrm{X}$ linkage. Firstly, males may not always be clinically affected ${ }^{78}$ and indeed the first large pedigree of this type of mental retardation, the Martin-Bell pedigree, contained two healthy males likely to have been carriers. ${ }^{9}$ Secondly, female carriers may be mentally retarded, ${ }^{81(1-12}$ although this is usually of mild degree.

Although it is not possible to determine the frequency of the fragile $\mathrm{X}$ syndrome from individual case reports, the large numbers of the latter since 1974 have suggested that the syndrome is not 
uncommon. There have been two estimates of the population frequency of the fragile $\mathrm{X}$ syndrome, one from Canada ${ }^{13}$ and the other from Australia. ${ }^{14}$ These estimates were based on the observed excess of brother-brother pairs with severe mental retardation over and above the number of affected sistersister pairs; the assessment of the proportion of $\mathrm{X}$ linked mental retardation due to the fragile $X$ syndrome; and the extrapolation of the data to the general population. These two estimates vary by a factor of five! Herbst and Miller ${ }^{13}$ estimated the prevalence of the fragile $\mathrm{X}$ syndrome in British Columbia to be 0.92 per 1000 male births, whereas a study from Australia ${ }^{14}$ estimated a prevalence of $0 \cdot 19$ per 1000 males. Two community studies from Sweden have demonstrated a prevalence of the fragile $\mathrm{X}$ chromosome of $6 \%$ in severely mentally retarded boys ${ }^{15}$ and $3 \%$ in mildly retarded children of both sexes. ${ }^{16}$

\section{Aims of study}

We planned a community study in order to assess the overall contribution of the fragile $\mathrm{X}$ chromosome to mental retardation. We also wished to assess the clinical features of the fragile $\mathrm{X}$ syndrome in patients who had been ascertained without bias. Because the technique for demonstrating the fragile $\mathrm{X}$ chromosome is laborious (see Methods section) we decided to exclude two groups of children in whom we did not expect to find the fragile $X$ chromosome. These two groups consisted of children who had a specific cause for their retardation, and girls who were severely retarded. We therefore proposed to study males with severe mental retardation $(\mathrm{ESN}(\mathrm{S}))$ of unexplained aetiology, and both males and females with unexplained mild mental retardation $(\mathrm{ESN}(\mathrm{M}))$. The present report describes the findings in the first group: boys with severe, idiopathic mental retardation.

\section{Methods}

POPULATION

We chose to study those boys requiring $\operatorname{ESN}(\mathrm{S})$ education who lived in the mixed urban and rural areas covered by six Education Authorities: Coventry, Central, North, East, and South Warwickshire, and Walsall. Permission to carry out the study was obtained from local ethical committees and the Education Authorities. The boys requiring ESN(S) education were mostly living at home and attending day schools, but a few were in residential institutions. The date 31 August 1978 was taken as the lowest date of birth of boys studied, in order to avoid possible bias in including some but not all boys who entered school during the two years of the study.

Firstly, the school or hospital medical records were scrutinised so that boys with a definite cause for their severe mental retardation were excluded from further study. For example, an account of severe birth asphyxia and subsequent neurological deficit led to a boy being excluded with a diagnosis of cerebral palsy. Birth hypoxia of uncertain severity or duration did not on its own lead to automatic exclusion.

Once these exclusions had been made, the parents of the remaining boys were asked for permission to examine and take blood from their sons. These boys were then examined by two Clinical Assistants (AT and JT) who particularly recorded measurements that had been reported as being abnormal in the fragile $\mathrm{X}$ syndrome. Birth weight and current heights and weights were compared to the centile standards of Gairdner and Pearson ${ }^{17}$ and the Tanner and Whitehouse charts. ${ }^{18}$ The head circumferences were compared to the normal scales of Westrupp and Barber, ${ }^{19}$ Nellhaus, ${ }^{20}$ and Tanner. ${ }^{18}$ Testicular volume was measured using a Prader orchidometer and was compared to the normal ranges described by Waaler $e t a^{21}$ and Taranger et al. ${ }^{22}$ Measurements of hand and foot size were also made and a neurological examination was performed. After this examination, blood was taken for haematological indices and chromosome studies.

IQ tests were only available for a minority of the boys and because of this an assessment of IQ range was made using the Vineland Social Maturity Scales, combined with an assessment by the head teachers. The procedure was as follows: the boys were categorised into IQ range by their teachers using the Vineland Social Maturity Scales. The IQ groups were then checked by the head teacher and if he/she considered that any child's social behaviour did not reflect their innate intelligence, then that child was moved to a more appropriate IQ group.

Next, the parents were visited at home and further information was obtained about the boy's early development and a pedigree taken. In the subsequent analysis we wished to compare the pedigrees of boys with the fragile $\mathrm{X}$ chromosome with those of boys without this cytogenetic abnormality. However, since the pedigrees of patients with the fragile $\mathrm{X}$ chromosome can be unusual (see above) we chose to define, for the purposes of this study only, an X linked pedigree as being one in which a maternal male relative (other than a brother) had severe, idiopathic mental retardation that appeared similar to that in the index patient. The presence of a retarded female relative did not prevent a pedigree from being labelled ' $\mathrm{X}$ linked'. 


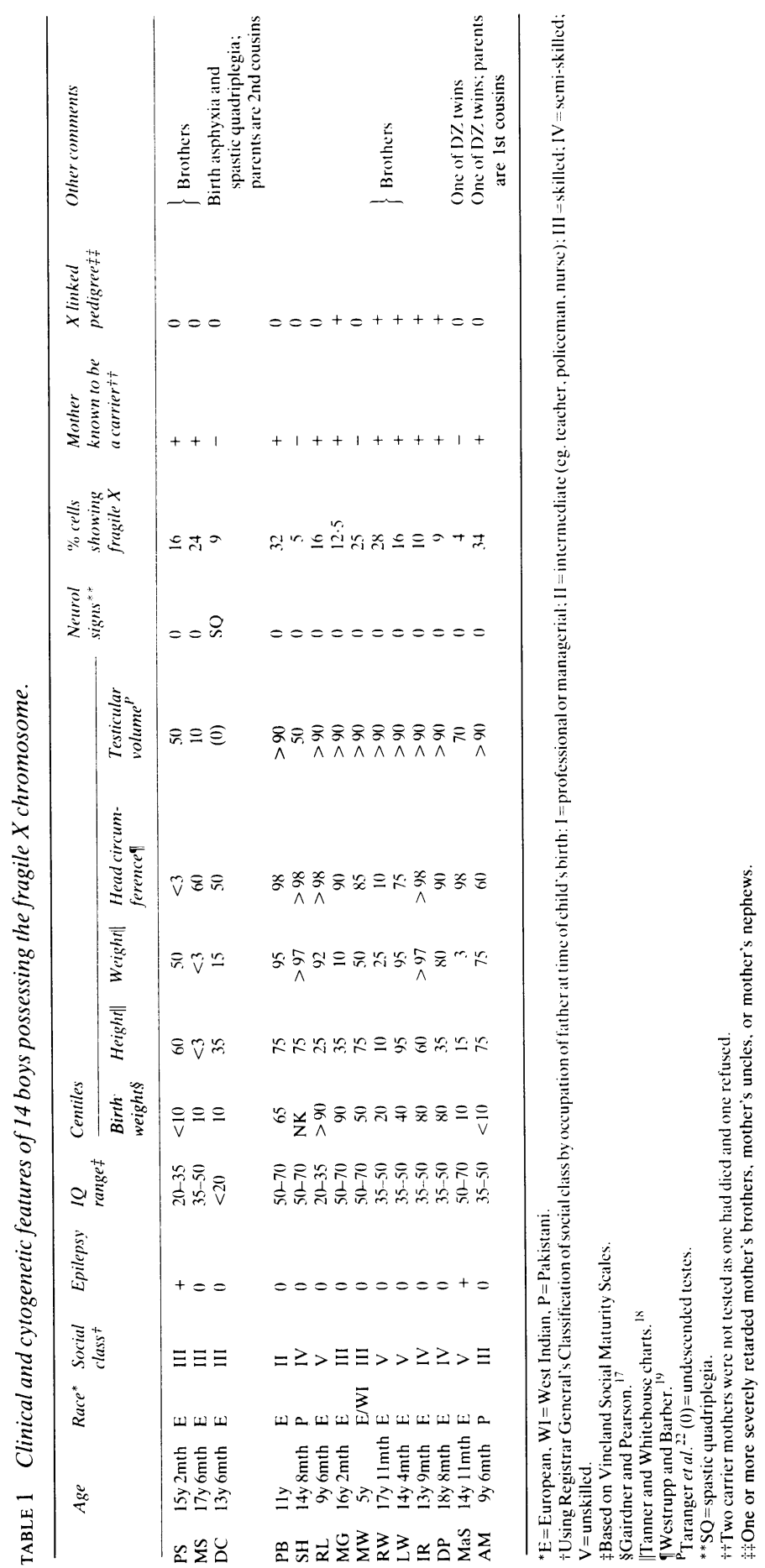


CYTOGENETIC TECHNIQUES

It had been previously shown by Sutherland ${ }^{23}$ that the fragile $X(q 27-28)$, in common with most other fragile sites, is only demonstrable after culture of cells in media deficient in both folic acid and thymidine. The marker is also only ever detectable in a percentage of mitoses which rarely if ever reaches $50 \%$. Consequently, several cultures were employed for each blood sample using both straightforward deficiency of folic acid and thymidine and also the antagonists MTX and FUdR. In this way' it was hoped to maximise the detection of the fragile $\mathrm{X}$ syndrome in this population. In each case on day 1 an aliquot $(0.4 \mathrm{ml})$ of whole blood was added to $5 \mathrm{ml}$ of: (1) TC199 + 2\% fetal calf serum (FCS): (2) TC199 $+2 \%$ FCS made $10^{-7} \mathrm{~mol} / \mathrm{l}$ in methotrexate (MTX); and (3) medium M (an adaptation of Ham's F10 without folic acid or thymidine) $+2 \%$ FCS. On day 2 a further two cultures were established: (1) TC199 + $2 \%$ FCS (using a different batch of medium) and (2) TC199 + 2\% FCS with the addition after 48 hours of culture time of $10^{-7} \mathrm{~mol} / \mathrm{l} \mathrm{FUdR}$. After 72 hours' culture time chromosome preparations were obtained by routine methods.

At least 50 mitoses were examined from each subject from the TC199 + 2\% FCS culture, and it is the percentage of $\operatorname{fra}(\mathrm{X})$ found in these cultures which is presented in table 1 . In addition, where possible, 25 cells were studied from the culture containing MTX and 25 from that containing FUdR. The cells grown in the kinder medium $M$ were subjected to routine Giemsa banding in order to identify any fragile site as being on the $\mathrm{X}$ chromosome at q27-28 and also to check whether those patients who did not have the fragile $\mathrm{X}$ syndrome were cytogenetically normal. Care was taken to ensure that a reasonable number of mitoses were obtained from each subject so that the family need not be approached again, while subjecting the cultures to the harsh conditions necessary to demonstrate the $\mathrm{fra}(\mathrm{X})$ with confidence. It was felt that a level of $4 \%$ or more of $\mathrm{fra}(\mathrm{X})$ constituted a positive finding. In each case the slides were analysed after solid staining but the presence of $\mathrm{fra}(\mathrm{X})$ was confirmed in each case by Giemsa banding.

\section{Results}

\section{WHOLE STUDY GROUP}

There were 289 females and 360 males requiring ESN(S) education in the areas studied (table 2). All the females were excluded from the study, as were 185 boys who had specific causes for their retardation; these are broadly categorised in table 3 . Of the 175 boys selected for the study, parental permission to examine and take blood from them was obtained from $156(89 \%)$. These 156 boys therefore form the basis of our study.

The ages of these 156 boys ranged from 5 to 19 years. One hundred and forty-eight boys were living

TABLE 3 Broad diagnostic categories of boys who were excluded.

\begin{tabular}{lcc}
\hline & $\begin{array}{l}\text { By initial perusal of } \\
\text { school medical } \\
\text { records }\end{array}$ & $\begin{array}{l}\text { After examination of boy } \\
\text { and history from parents }\end{array}$ \\
\hline Intrauterine infection & 4 & 1 \\
Cerebral palsyt & 34 & 14 \\
Neonatal illness & 8 & 4 \\
Postnatal infection or trauma & 14 & 2 \\
Down's syndrome or other & 94 & 2 \\
$\quad$ chromosome abnormality & 12 & 2 \\
Malformation syndromes & 19 & 14 \\
Other syndromes & 185 & 39 \\
Totals & & \\
\hline
\end{tabular}

*These children were tested for the fragile $X$ chromosome: 1 in 39 was positive. +Either an obvious history of hypoxia or trauma at birth, or asymmetrical neurological signs, or both

TABLE 2 Numbers of children at $\operatorname{ESN}(S)$ schools and the numbers of those studied.

\begin{tabular}{|c|c|c|c|c|c|c|}
\hline $\begin{array}{l}\text { Area studied } \\
\text { (Numbers in parentheses refer to total } \\
\text { population * followed by number of } \\
\text { school childrent) }\end{array}$ & $\begin{array}{l}\text { Total } \\
\text { females }\end{array}$ & $\begin{array}{l}\text { Total } \\
\text { males }\end{array}$ & $\begin{array}{l}\text { Males deliberately } \\
\text { excluded (see text) }\end{array}$ & $\begin{array}{l}\text { Males selected } \\
\text { but parents refused }\end{array}$ & $\begin{array}{l}\text { Males } \\
\text { studied }\end{array}$ & $\begin{array}{l}\text { Males with } \\
\text { fragile } X\end{array}$ \\
\hline $\begin{array}{l}\text { Coventry } \\
\quad(319500 ; 55941)\end{array}$ & 94 & 124 & $60 \ddagger$ & 4 & $60 \$$ & 6 \\
\hline $\begin{array}{l}\text { Central and South Warwickshire } \\
\quad(215800 ; 35280)\end{array}$ & 45 & 54 & 26 & 7 & 21 & 0 \\
\hline $\begin{array}{l}\text { North Warwickshire } \\
\quad(174000 ; 33317)\end{array}$ & 46 & 63 & 38 & 3 & 22 & 5 \\
\hline $\begin{array}{l}\text { East Warwickshire } \\
\quad(87500 ; 13769)\end{array}$ & 24 & 29 & 13 & 2 & 14 & 0 \\
\hline $\begin{array}{l}\text { Walsall } \\
\qquad(267800 ; 52628)\end{array}$ & 80 & 90 & 48 & 3 & 39 & 3 \\
\hline Total numbers & 289 & 360 & 185 & 19 & 156 & 14 \\
\hline
\end{tabular}

*These population figures are mid-1981 estimates obtained from the West Midlands County Council Annual Abstract of Statistics, 1983.

tFigures kindly supplied by the Education Officers for the six areas and relate to 1981-1982.

‡Figure includes 10 boys at residential ESN(S) schools for whom no corresponding numbers of females are available.

§Figure similarly includes eight boys at residential schools. 
at home and attending $\operatorname{ESN}(\mathrm{S})$ day schools; eight $(5.4 \%)$ were in residential institutions. The racial distribution of the boys was mixed, as shown by the percentages given in table 4 and the actual numbers in table 5. The IQ distribution of the boys studied, as assessed by the Vineland Social Maturity Scales (after adjustment), is shown in table 6.

\section{EXCLUSION OF A FURTHER 39 BOYS}

After clinical assessment (physical examination and parental interview) it was considered that 39 of these 156 boys had a specific cause for their mental retardation, as summarised in table 3 . It was interesting that among the 14 boys classified as having cerebral palsy there was one who was $47, X X Y$ and one who had the fragile X chromosome. Of two boys subsequently found to have chromosome abnormalities, one had an additional de novo $15 q 15 q$ marker chromosome and one had an unbalanced abnormality of chromosome 3 . In addition, but not counted with the 39 excluded boys, one boy had a fragile site on chromosome 22 , which may or may not have contributed to his mental retardation. ${ }^{24}$

It was considered that among the 16 boys with malformation or other syndromes (table 3 ) there were some autosomal recessive entities: simple microcephaly; microcephaly with spastic quadriple-
TABLE 6 IQ range (on adjusted Vineland Social Maturity Scale) and population studied.

\begin{tabular}{lccc}
\hline IQ range & $\begin{array}{l}\text { Boys who were } \\
\text { deliberately excluded }\end{array}$ & $\begin{array}{l}\text { Boys who were } \\
\text { studied }\end{array}$ & $\begin{array}{l}\text { Boys with } \\
\text { fragile } X\end{array}$ \\
\hline $70+$ & 3 & 3 & 0 \\
$50-69$ & 25 & 30 & 5 \\
$35-49$ & 75 & 59 & 6 \\
$20-34$ & 35 & 43 & 2 \\
Under 20 & 28 & 21 & 1 \\
Totals & 166 & 156 & 14 \\
\hline
\end{tabular}

* 19 boys were not tested: seven had left school before the Vineland assessment was carried out and 12 boys attended one school in which no IQ assessments werc performed.

gia; spastic quadriplegia with normal sized head; and microcephaly with colobomata. In the families of these 16 index patients there were five sets of consanguineous parents and three out of 28 sibs were $\operatorname{ESN}(\mathrm{S})$.

\section{CYTOGENETIC RESULTS}

There were 14 out of the 156 boys $(8.9 \%)$ studied who possessed the fragile $\mathrm{X}$ chromosome, in percentages of their cells ranging from 4 to $32 \%$. If the 39 boys subsequently thought to have a specific cause for their retardation are excluded, the prevalence of the fragile $\mathrm{X}$ among those without a diagnosis becomes 13 in 117 or $11.1 \%$.

TABLE 4 Racial distribution of schoolchildren in areas studied (in percentages).

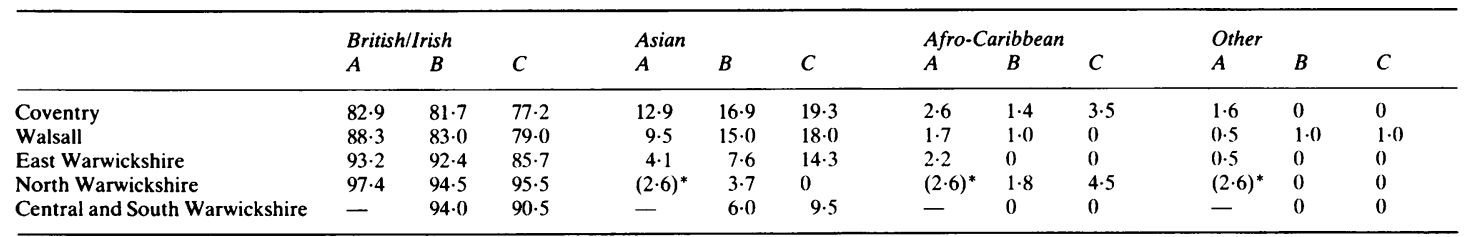

$A=$ percentage racial distribution in total school population as supplied by the Department of Education for Coventry, Walsall, East and North Warwickshire. $\mathrm{B}=$ percentage racial distribution in $\operatorname{ESN}(\mathrm{S})$ schools.

$\mathrm{C}=$ percentage racial distribution in boys with idiopathic severe mental retardation; these were the boys studied.

*In North Warwickshire only the total numbers of immigrants among school children is known; they have not been divided by race.

TABLE 5 Genetic categories of index patients.

\begin{tabular}{|c|c|c|c|c|c|}
\hline & $\begin{array}{l}\text { No of boys } \\
\text { studied }\end{array}$ & $\begin{array}{l}\text { No with } \\
\text { consanguineous } \\
\text { parents* }\end{array}$ & $\begin{array}{l}\text { No with } \\
\text { probable } A R \\
\text { diseaset }\end{array}$ & $\begin{array}{l}\text { No with } \\
\text { probable } X L \\
\text { disease }\end{array}$ & $\begin{array}{l}\text { No with } \\
\text { fragile } \\
\text { X chromosome }\end{array}$ \\
\hline Other European & 2 & 1 & 1 & 0 & 0 \\
\hline $\begin{array}{l}\text { West Indian and } \\
\text { West Indian/English }\end{array}$ & 4 & 0 & 0 & 1 & 1 \\
\hline Pakistani & 8 & 6 & 4 & 2 & 2 \\
\hline Totals & 156 & 10 & 16 & 22 & 14 \\
\hline
\end{tabular}

*No information was available for seven British index patients

tClinical features of AR microcephaly and/or spastic quadriplegia, and/or an ESN(S) sib. (This figure includes five index patients with ESN(S) brothers but no other evidence of XL disease.)

$\ddagger$ A maternal male relative (other than a brother) who was $\mathrm{ESN}(\mathrm{S})$, and/or the index patient had the fragile $\mathrm{X}$ chromosome.

$\mathrm{AR}=$ autosomal recessive, $\mathrm{XL}=\mathrm{X}$ linked recessive. 
CLINICAL FEATURES OF THE 14 BOYS WITH THE FRAGILE X CHROMOSOME

These are summarised in table 1 . There were 11 British patients, one who had a Jamaican father and an English mother, and two who were Pakistani. With one exception, their IQs were above 20 points, and 11 were in IQ ranges over 35 (table 6). The exception was a spastic boy who had severe birth asphyxia and who was considered to have cerebral palsy; this boy's parents were consanguineous. There was no altered distribution of birth -weight, height, or weight of these 14 boys with the fragile $X$ chromosome, as judged by the normal centiles for their age (table 1).

In contrast, the distributions for head circumference and testicular volume were abnormal, the affected boys tending to have big heads and big testes. Only three of the 14 affected boys had a head circumference at the 50th centile or below, seven boys had a head circumference at the 90 th centile or above, and three had a head circumference over the 98th centile. There was no significant correlation between head circumference and height, nor between head circumference and testicular size.

One boy had undescended testes; of the remaining 13 boys, nine had testicular volumes over the 90 th centile. Actual volumes over $25 \mathrm{ml}$ (the largest volume on the Prader orchidometer) were not recorded.

\section{GENETIC DATA OF THE WHOLE GROUP}

A pedigree was available for only 149 of the 156 boys, for the natural parents of seven boys could not be contacted. Ten parental couples were consanguineous; six of these were in Muslim families (table 5).

The group of boys selected for the study had a high risk of recurrence of mental subnormality in sibs (table 7). For all 156 boys, the occurrence of severe mental subnormality in brothers was 1 in 8 and in sisters was 1 in 24 . However, the risk for brothers was greater for the 14 index patients with the fragile $X$ chromosome (1 in 3.4) than for the brothers of the 142 boys without the fragile $\mathrm{X}$ chromosome (1 in 10). The risk of mild mental subnormality was 1 in 17 for brothers and 1 in 13 for sisters.
There were 18 out of the 149 index patients who had one or more sibs with a similar type of severe mental retardation (one severely retarded sister with spina bifida is not counted here). Among these 18 were five boys who had the fragile $\mathrm{X}$ chromosome and four others with an $\mathrm{X}$ linked pedigree. This left nine index patients with severely retarded sibs and no evidence of $X$ linkage; five of these had affected brothers only, four had affected sisters only, and one had both an affected brother and sister.

There were 13 out of the 149 index patients who had an $\mathrm{X}$ linked pedigree as defined earlier; nine of their 24 brothers were $\mathrm{ESN}(\mathrm{S})$. Of these 13 index patients five were found to carry the fragile $X$ chromosome, while eight did not.

GENETIC DATA OF THE 14 INDEX PATIENTS WITH THE FRAGILE $X$ CHROMOSOME

Since there were two pairs of brothers, the 14 boys with the fragile $X$ came from 12 families. Two sets of parents were consanguineous. Five out of 17 brothers were severely mentally retarded and two out of 17 sisters were mildly mentally retarded. Eight mothers were carriers, either because they showed the chromosome abnormality (four mothers) or because their relatives did. Of these latter four mothers, two were chromosomally normal and two could not be tested.

Five of these 14 index patients had an $\mathrm{X}$ linked pedigree. Four index patients had sibs only affected and there were no mentally retarded relatives in five of the 12 families. In one of these the mother and sister showed the fragile $\mathrm{X}$ chromosome, but in the remaining four families no mother and no other relative (two brothers of index patients, four sisters, one maternal aunt, and two maternal grandparents) were found to have the fragile $\mathrm{X}$ chromosome.

Of the 17 sisters six had the fragile $X$ chromosome (one was counted twice as she had two index patients as brothers), seven did not, three had borderline results, and one was not tested.

Of the 17 brothers, five had the fragile $\mathrm{X}$ chromosome (four were also index patients), 11 did not (three were counted twice as each had two index patients as brothers), and one was not tested.

TABLE 7 Mental subnormality in sibs.

\begin{tabular}{|c|c|c|c|c|c|}
\hline & \multicolumn{2}{|c|}{$E S N(S)$ sibs out of total } & \multicolumn{2}{|c|}{$E S N(M)$ sibs out of total } & \multirow[t]{2}{*}{ All ESN sibs out of total } \\
\hline & Brothers & Sisters & Brothers & Sisters & \\
\hline $\begin{array}{l}142 \text { boys without the fra }(X) \\
14 \text { boys with the fra }(X) \\
156 \text { boys in study }\end{array}$ & $\begin{array}{l}13 / 135 \\
5 / 17 \\
18 / 152\end{array}$ & $\begin{array}{l}5 / 104 \\
0 / 17 \\
5 / 121\end{array}$ & $\begin{array}{l}9 / 135 \\
0 / 17 \\
9 / 152\end{array}$ & $\begin{array}{l}7 / 104 \\
2 / 17 \\
9 / 121\end{array}$ & $\begin{array}{l}34 / 239 \\
7 / 34 \\
41 / 273\end{array}$ \\
\hline
\end{tabular}




\section{Discussion}

There are several observations of interest that have been demonstrated by this community study. Firstly, the boys selected for the study had a high recurrence rate of severe subnormality among their sibs. Secondly, there was a significant proportion of boys with $\mathrm{X}$ linked disease, of whom only some displayed the fragile $X$ chromosome. Thirdly, the prevalence of the fragile $\mathrm{X}$ chromosome was high.

THE WHOLE GROUP

Our selection of $156 \mathrm{ESN}(\mathrm{S})$ boys with idiopathic severe mental retardation has led to the identification of a group with a high risk of recurrence for sibs, particularly for brothers. The overall recurrence of severe mental retardation in sibs was 1 in 12 and in brothers 1 in 8 (table 7): This recurrence is higher than that usually found for severe idiopathic mental retardation and is higher than that found in a recent large family study from British Columbia. ${ }^{1}$ In this Canadian study, the recurrence rate of mental retardation in sibs of index patients who were retarded without any associated features was 1 in 15 for brothers and 1 in 24 for sisters.

The high recurrence rate in our study is likely to be due to both autosomal recessive and $\mathrm{X}$ linked inheritance. The evidence for autosomal recessive inheritance is threefold. Firstly, nine boys (five British, four Pakistani) had clinical features of an autosomal recessive syndrome: microcephaly; microcephaly with spastic quadriplegia; microcephaly with colobomata; spastic quadriplegia with normocephaly. Secondly, there was an increased rate of parental consanguinity, certainly for British/Irish parental couples of whom three of 121 were consanguineous. The consanguinity rate for the parents of the Pakistani children was high (six out of eight parental couples) but we do not think that this is higher than the consanguinity rate among all immigrant Pakistanis in the West Midlands. Thirdly, there was the occurrence of the same type of severe mental retardation in the sibs of nine index patients who did not have evidence of $\mathrm{X}$ linked disease.

It is interesting to consider the racial distribution of the boys studied in relation to the possible excess of autosomal recessive disease in Muslims from Pakistan. The racial distribution of children in the ESN(S) schools and of the boys studied is shown in table 4 . There is a greater proportion than expected of severely retarded Asian children, but not of West Indian children, in the $\operatorname{ESN}(\mathrm{S})$ schools. Moreover, this proportion increases further in the children with idiopathic retardation who were selected for study. These increasing proportions suggest that there might be an excess of autosomal recessive disease among Asians, perhaps particularly in the Muslims because of their high consanguinity rate. Among the boys with the fragile $X$ chromosome (table 1) the racial distribution was consistent with that of the local population.

The evidence for $\mathrm{X}$ linked genes in the entire sample comes from two facts. Firstly, the recurrence risk for severe mental retardation for brothers was three times that for sisters and, secondly, 13 index patients had 'an X linked pedigree' as defined rather loosely for the study. However, the fragile $X$ chromosome did not account for all the $\mathrm{X}$ linked mental retardation, probably for about two-thirds (table 5), or less if some of the five index patients with $\operatorname{ESN}(S)$ brothers but no other affected relatives had $\mathrm{X}$ linked rather than autosomal recessive disease.

\section{THE PREVALENCE OF THE FRAGILE X}

CHROMOSOME

We decided to take the occurrence of the fragile $\mathrm{X}$ chromosome in $4 \%$ of cells as the diagnostic criterion for the fragile $\mathrm{X}$ syndrome. This was because it is necessary to subject the lymphocytes to very harsh culture conditions in order to be reasonably certain of detecting the chromosome abnormality. Such conditions, particularly the presence of FUdR and MTX, cause a background level of random chromosome damage. A cut-off level of $4 \%$ eliminates the finding of false positives due to these induced aberrations.

The overall prevalence of the fragile $\mathrm{X}$ chromosome in $\operatorname{ESN}(\mathrm{S})$ boys of about $9 \%$ is very high, and it rises to $11 \%$ if 39 boys with specific clinical features are excluded. It is not known whether the prevalence would change if the 19 boys whose parents withheld permission had been studied. We do know that one of the 19 had the fragile $X$ chromosome, for he was a cousin of an index patient and his general practitioner subsequently obtained a blood sample. The high prevalence indicates that chromosome studies in folic acid and thymidine deficient medium should be performed on all boys with severe, unexplained mental retardation.

Since the start of our survey, community studies on the prevalence of the fragile $\mathrm{X}$ chromosome in severely and mildly mentally retarded children have been reported from Sweden. ${ }^{15} 16$ In the first of these, Blomquist et al ${ }^{15}$ investigated an unselected consecutive series of boys with severe mental retardation. The overall prevalence of the fragile $X$ chromosome was six out of 96 , but was as high as six out of 29 among the severely retarded boys with no obvious cause (other than a genetic one) for their mental retardation.

The prevalence of the fragile $\mathrm{X}$ chromosome in 
severely retarded males in institutions is lower than that of the community studies from the West Midlands or Sweden. Figures ranging from 1 to $6 \%$ have been found. ${ }^{25-27}$ This is not surprising in view of the observations by Turner $e a^{28}$ that males with $X$ linked mental retardation have no neurological signs, an IQ usually above 35 , and amenable natures, all features which would lead to an affected male being cared for in the community rather than in an institution.

THE BOYS WITH THE FRAGILE X CHROMOSOME The clinical features of the 14 boys ascertained in the study have been summarised in table 1 , and show that the only obvious features are an IQ in the range 35 to 70 , large heads, and large testes. However, only eight of the 14 boys had IQs in this range, together with head circumference and testicular volume above the 50th centile, and two boys had none of these three features. We found no association of the fragile $\mathrm{X}$ chromosome with high birth weights or greater than average heights.

Gustavson et al ${ }^{29}$ observed that the mental retardation of males with the fragile $\mathrm{X}$ chromosome was often in the mild range (IQ 50 to 70), but he did not describe the psychological tests which were used to define IQ range. In our series, using adjusted Vineland Social Maturity Scales, 11 of the 14 patients were in the IQ range 35 to 70 (table 6).

The cytogenetic studies in the 12 families ascertained will be further discussed by Webb et al in a subsequent paper in preparation. However, it appears that four of the fragile $\mathrm{X}$ index patients could be new mutants, although this cannot be known with certainty until a definitive test for the female carrier state becomes available. The four boys came from families where no other case of mental retardation was ascertained, and where we could not demonstrate the fragile $\mathrm{X}$ chromosome in mothers or in any other relative. It will be interesting to determine the carrier status of these four mothers when there is a definitive test, in view of the suggestion from Sherman of $a l^{12}$ that new mutations in boys are very rare and that most mothers are carriers.

We are grateful to the National Fund for Research into Crippling Diseases (Action Research for the Crippled Child), the Mental Health Foundation, and the West Midlands Regional Health Authority for financial support for this study. We thank Mrs G Snawdon for technical assistance. We are indebted to the head teachers and staff of the schools studied, and to the Education Officers for their active and willing cooperation. We also thank Dr Hommers and the Clinical Medical Officers of the areas concerned. We are grateful to Professor
A S McNeish and Dr $J$ Insley for their advice in preparing this manuscript, and we thank Mrs Jennifer Pickering and Miss Valerie Bailey for secretarial help during the study.

\section{References}

1 Herbst DS, Baird PA. Sib risks for nonspecific mental retardation in British Columbia. Am J Med Genet 1982:13:197-208.

2 Davison BCC. Familial idiopathic severe subnormality: the question of a contribution by X-linked genes. In: Genetic studies in mental subnormality. Br J Psychiatry 1973: Special publication No 8 .

3 Turner G, Turner B. X-linked mental retardation. J Med Genet 1974;11:109-13.

4 Lubs HA. A marker X chromosome. Am J Hum Genet 1969;21:231-44.

5 Harvey J, Judge C, Weiner S. Familial X-linked mental retardation with an $\mathrm{X}$ chromosome abnormality. $J$ Med Genet 1977;14:46-50.

6 Sutherland GR. Heritable fragile sites on human chromosomes. Hum Genet 1979;63:23-7.

7 Camerino G, Mattei MG, Mattei JF, Jaye M, Mandel JL. Close linkage of fragile X-mental retardation syndrome to hacmophilia $B$, and transmission through a normal malc. Nature 1983;306:701-4.

$\checkmark$ Nielsen KB, Tommerup N, Poulsen H, Mikkelsen M. X-linked mental retardation with fragile $X$. A pedigree showing transmission by apparently unaffected males and partial cxpression in female carriers. Hum Genet 1981:59:23-5.

${ }^{9}$ Richards BW, Sylvester PE, Brooker C. Fragile X-linked mental retardation: the Martin-Bell syndrome. J Ment Defic Res $1981 ; 25: 253-6$.

10 Turner G, Brookwell R, Daniel A. Selikowitz M. Zilibowitz M. Heterozygous expression of $\mathrm{X}$-linked mental retardation and $\mathrm{X}$-chromosome marker fra(X) (q27). N Engl J Med 1980;303:662-4.

11 Chudley AE, Knoll J, Gerrard JW. Shepel L, McGahey E, Anderson J. Fragile (X) X-linked mental retardation. I. Relationship between age and intelligence and the frequency of expression of fragile (X) (q28). Am J Med Genet 1983;14:699712 .

12 Sherman SL, Morton NE, Jacobs PA, Turner G. The marker (X) syndrome: a cytogenetic and genetic analysis. Ann Hum Genet 1984;48:21-37.

13 Herbst DS, Miller JR. Non-specific X-linked mental retardation. Il. The frequency in British Columbia. Am J Med Genet 1980;7:461-9.

14 Fishburn J, Turner G, Daniel A, Brookwell R. The diagnosis and frequency of $\mathrm{X}$-linked conditions in a cohort of moderately retarded males with affected brothers. Am J Med Genet 1983;14:713-24.

15 Blomquist HK, Gustavson KH, Holmgren G, Nordenson I, Sweins A. Fragile site $\mathrm{X}$ chromosomes and $\mathrm{X}$-linked mental retardation in severely retarded boys in a Northern Swedish County. A prevalence study. Clin Genet 1982;21:209-14.

16 Blomquist HK, Gustavson KH, Holmgren G, Nordenson I. Pålsson-Stråe $U$. Fragile $X$ syndrome in mildly mentally retarded children in a Northern Swedish county. A prevalence study. Clin Genet 1983;24:393-8.

17 Gairdner D, Pearson J. A growth chart for premature and other infants. Arch Dis Child 1971;46:783-7.

is Tanner JM. Physical growth and development. In: Forfar JO, Arneil GC, eds. Textbook of paediatrics. Edinburgh, London: Churchill Livingstone, 1984: chap 7.

19 Westrupp CK. Barber CR. Growth of the skull in young children. J Neurol Neurosurg Psychiatry 1956;19:52-6.

21) Nellhaus G. Head circumference from birth to eighteen years. Pediatrics 1968;41:106-14. 
21 Waaler PE, Thorsen T, Stoa KF, Aarskog D. Studies in normal male puberty. Acta Paediatr Scand [Suppl] 1974;249:1-36.

22 Taranger J, Engström I, Lichtenstein H. Svennberg-Redegren I. Somatic pubertal development. Acta Paediatr Scand /Suppl] 1976:258:121-35.

23 Sutherland GR. Heritable fragile sites on human chromosomes. Factors affecting expression in lymphocyte culture. Am J Hum Genet 1979;31:125-35.

24 Webb TP. Thake A. Fragile $22 \mathrm{q} 13$ segregating in a family. Clin Genet 1984;26:125-8

25 Jacobs PA. Mayer M, Matsuura J, Rhoads F. Yee SC. A cytogenetic study of a population of mentally retarded males with special reference to the marker (X) syndrome. Hum Genet 1983:63:139-48.

26 Froster-Iskenius J. Felsch G, Schirren C. Schwinger E. Screening for fra $(\mathrm{X})(\mathrm{q})$ in a population of mentally retarded males. Hum Genet 1983;63:153-7.
27 Kähkönen $M$, Leisti J, Wilska $M$, Varonen S. Marker Xassociated mental retardation. A study of 150 retarded males. Clin Genet 1983:23:397-404.

28 Turner G, Turner B, Collins E. X-linked mental retardation without physical abnormality. Dev Med Child Neurol 1971:13:71-8.

${ }^{29}$ Gustavson KH, Holmgren G, Blomquist HK, et al. Familial $\mathrm{X}$-linked mental retardation and fragile $\mathrm{X}$ chromosome in two Swedish families. Clin Genet 1981;19:101-10.

Correspondence and requests for reprints to $\operatorname{Dr} S$ Bundey, Department of Clinical Genetics, Infant Development Unit, Birmingham Maternity Hospital, Edgbaston, Birmingham B15 2TG. 